\title{
Texto e ilustración en la narrativa argentina del siglo XIX
}

Recibido: 9/4/2018. Aprobado: 31/5/2018.

\begin{abstract}
Resumen
Tras la revolución editorial que se cumple en Europa en el campo de las publicaciones ilustradas en la tercera década del siglo XIX, también la novela hispanoamericana explora desde sus comienzos las posibilidades semántico-expresivas de la ilustración, según los medios técnicos y los saberes disponibles en cada uno de los contextos regionales en los que se experimenta. Se analiza, aquí, el caso de la narrativa ilustrada argentina que, desde 1870 y por dos décadas, da cuenta de la anexión violenta de los territorios indígenas a la geografía nacional. En particular, se analizarán los casos de Una excursión a los indios ranqueles, de Lucio V. Mansilla, en sus ediciones de 1870 y 1890 , y de Viaje al país de los Araucanos (1881) y Relmu, la reina de los pinares (1893), de Estanislao S. Zeballos.
\end{abstract}

\section{Text and illustrated editions in the argentine narrative of the XIX Century}

\footnotetext{
Abstract

After the publishing revolution that takes place in Europe in the field of illustrated editions, in the third decade of the nineteenth century, the Spanish-American novel also explores the possibilities of illustration, according to the technical means and the knowledge available in each of the regional contexts in which it is experienced. This essay focuses on the case of the illustrated Argentine narrative that, from 1870 and for two decades, gives an account of the military annexation of indigenous territories to the national geography. In particular, the essay analyzes the cases of Una excursión a los indios ranqueles, by Lucio V. Mansilla, in its editions of 1870 and 1890 , and of Viaje al país de los Araucanos (1881) and Relmu, la reina de los pinares (1893), by Estanislao S. Zeballos.
}

Palabras lave

Ilustración Argentina Siglo XIX Lucio V. Mansilla Estanislao S. Zeballos 


\section{Palavras-chave}

llustração Argentina século XIX

Lucio V. Mansilla

Estanislau S. Zeballos
1. Como proponen Liliane Louvel y Henri Scepi, confrontar el texto y la imagen significa darse la posibilidad de reconfigurar las nociones y repensar los objetos sustrayéndolos del imperio de las discursividades especializadas: por un lado la historia del arte, por el otro la crítica literaria y en especial la teoría del texto (Louvel y Scepi: 13).
2. Vale la pena citar el pasaje por entero: "Para ver esta cuestión en toda su amplitud, sería necesario no solo la información histórica que me falta, sino también una competencia técnica e iconológica (uno piensa en las viñetas y los frontispicios de la época clásica) que siempre me faltará. Este es un estudio que excede los límites del simple «literario»" (Genette: 351).

3. Baste mencionar, solo en la bibliografía más reciente citada en este trabajo, la constelación de los estudios de Graciela Batticuore, Silvia Dolinko, Marcela Gené, Mariana Giordano, Laura Malosetti Costa, Hernán Pas, Marta Penhos, Claudia Román, Graciela Silvestri, Sandra M. Szir.

\section{Resumo}

Após a revolução editorial que ocorre na Europa no campo das publicações ilustradas na terceira década do século XIX, também o romance hispano-americano explora desde os seus inícios as possibilidades semântico-expressivas de ilustração, de acordo com os meios técnicos e os conhecimentos disponíveis em cada um dos contextos regionais em que é experimentado. Aqui, analisamos o caso da narrativa argentina ilustrada que, a partir de 1870 e por duas décadas, dá conta da violenta anexação de territórios indígenas à geografia nacional. Em particular, analisaremos os casos de Una excursión a los indios Ranqueles, de Lucio V. Mansilla, em suas edições de 1870 e 1890, e de Viaje al país de los Araucanos (1881) e Relmu, la reina de los pinares (1893), de Estanislao S. Zeballos.

El marco teórico que presupone el estudio de las ilustraciones de textos literarios implica una enorme variedad de cuestionamientos, imposibles de enumerar aquí, suscitados por la confrontación razonada de las prácticas literarias con los artefactos artísticos visuales. El análisis de las relaciones entre texto e imagen excede hoy los límites de la reducción comparativa consolidada por la teoría de Lessing y sus seguidores, que confronta la diacronía de la narración con la sincronía de la representación figural, la mímesis con la deixis, y, más en general, aborda los distintos modelos de referencialidad propios de los códigos visual y verbal para constatar la irreductibilidad de lo visible y lo legible. El interés propiamente epistemológico de esta reflexión reside más bien en la dinámica de la interacción y en la posibilidad de modificar tanto la definición teórica del texto y de la imagen, como sus modos de producción y de interpretación. ${ }^{1}$

Por otra parte, desde hace ya varias décadas, la atención de los estudios literarios se ha enfocado en aquellos elementos paratextuales que las ciencias del texto, como la filología y la crítica literaria, han pasado tradicionalmente por alto, y que Genette ha dado en llamar umbrales. En particular, la ilustración aparece mencionada en el catálogo de paratextos formulado por Genette, para luego desaparecer en el desarrollo de sus argumentaciones y análisis. Ahora bien, ¿es la ilustración un umbral? La figura es sugerente: el ojo del lector transita por la imagen, entrando y saliendo del texto a través de ella, como por un espacio liminar en el que la imaginación negocia las maneras de visualizar lo que lee. Pero el paratexto de Genette es siempre un discurso auxiliar, al servicio del texto, sin el cual pierde de validez y sentido. Y las ilustraciones, en cambio, pueden gozar de vida propia, incluso pueden preceder el texto, como ciertas litografías del costumbrismo de principio del siglo XIX, que inspiraron los textos románticos hispanoamericanos de los años '30 y '40 y que después fueron utilizadas para ilustrar esos mismos textos. No por nada Genette se resiste finalmente a analizar las ilustraciones, declarándose incapaz de afrontar los múltiples retos del paratexto no verbal, un "inmenso continente" que "excede los límites del simple literario" ${ }^{2}$. Afortunadamente, las décadas que nos separan de esta declaración de imposibilidad han visto multiplicarse, por un lado, aquellas corrientes de estudios que se focalizan en la materialidad de los artefactos culturales, y que recuperan raíces semiológicas en aspectos del libro antes impensados o confinados dentro de específicos saberes técnicos, como las ciencias bibliográficas; por el otro lado, hemos asistido a la eclosión de los estudios sobre cultura visual que han abierto infinitas perspectivas para la comprensión de las imágenes, su significado histórico y sus usos sociales, dentro de disciplinas tradicionalmente muy compartimentadas, como la historia del arte. En Argentina, una ya importante bibliografía sobre cultura visual, cultura gráfica y prensa ilustrada -y también sobre la historia de la lectura, que apela justamente a la materialidad como uno de los registros de la representación- permite hoy situar ese objeto de estudio en un terreno menos escurridizo. ${ }^{3}$ 
En cuanto práctica editorial históricamente codificada, la ilustración de textos literarios conoce en el siglo XIX un giro importante, asociado con las innovaciones técnicas, los cambios en el hábito de la lectura y la ampliación del público lector. Como es obvio, dicha práctica, así como se configura entre la tercera década y las últimas del siglo XIX, período conocido como Siglo de Oro de la ilustración, es parte de la profunda transformación perceptiva y cultural decimonónica que, justamente a partir de la imagen impresa, y luego de la fotografía, resulta inseparable de un más vasto proceso de reorganización de las disciplinas científicas, las prácticas sociales, los modos de circulación y consumo de la cultura, surgido a raíz de la industrialización. Dejo de lado aquí, sin embargo, los productos más notables y novedosos de esta transformación, es decir, el folletín y la prensa periódica ilustrada (Pas, 2014), para tomar en consideración únicamente la ilustración de obras narrativas en volumen que, si bien heredera de tradiciones artísticas y literarias bien arraigadas en Occidente, se afirmará como expresión peculiar de las poéticas románticas. A partir de los países centrales, dicha práctica se extenderá a distintos sistemas literarios, entre ellos los hispanoamericanos, donde también se explorarán las posibilidades semántico-expresivas de la ilustración de novelas, según los medios técnicos y los saberes disponibles en cada uno de los contextos regionales en los que se experimenta. En México, heredero de la excepcional tradición visual y tipográfica novohispana, el fenómeno acompaña el nacimiento mismo del género novela a principio del siglo XIX, con la primera edición ilustrada del Periquillo sarniento de Fernández de Lizardi. En la Argentina, en cambio, para que la práctica de la ilustración literaria se afirme, habrá que esperar por lo menos la década del '70, cuando se consoliden los oficios que permitirán lograr un nivel satisfactorio de impresión de grabados y sobre todo de litografías en los establecimientos tipográficos del país. Si bien la impresión litográfica ya se practicaba a partir de los años '30, solo alcanzará niveles masivos de difusión con la introducción del fotograbado recién en los '90.

Por supuesto, las condiciones de producción no se definen únicamente por un determinismo tecnológico tan reductivo (Szir, 2016), sino que dependen de circunstancias mucho más complejas tales como, en las palabras de Laura Malosetti, "prácticas culturales, interacciones sociales, concepciones estéticas, conflictos de clase, raza, géneros e identificaciones políticas" (Malosetti y Gené, 2009: 10). La preocupación de Lizardi por las ilustraciones de su obra, testimoniada por los prospectos que promocionan la suscripción de las entregas, refleja su inédita figura de escritor profesional preocupado por las exigencias de un mercado incipiente y la consecuente formación de un público lector. En otro orden de ideas, las ilustraciones del Periquillo sarniento, que varían en las sucesivas ediciones de la novela, apelan a lo visual para amplificar el mensaje pedagógico del texto, al mismo tiempo que complejizan el juego de perspectivas de la narración. Los pasajes ilustrados, especialmente seleccionados por Lizardi, muestran al protagonista como víctima, en tanto que la narración en primera persona lo representa como agresor, desplazando la lectura hacia una reprobación más severa de sus actos. Plasmadas en directa relación con lo narrado, las láminas marcan una fuerte discontinuidad con la tradición visual virreinal en la representación de las tensiones sociales que se encuentran inscriptas en el texto: rompen la mirada falsamente armónica de las pinturas de castas al plasmar la violencia interracial, muestran la pluralidad social en interacciones conflictivas y responden al intento pedagógico del liberalismo lizardiano en vísperas de la reorganización social del México independiente (De Alba-Koch, 1999). Las imágenes, como demostrará el posterior desarrollo de la novela ilustrada mexicana - piénsese solo en el despliegue iconográfico de la serie novelesca de La linterna mágica de José Tomás de Cuéllar-serán determinantes para la imaginación de una comunidad nacional marcada por la pluriculturalidad, el mestizaje y el conflicto social.

El ejemplo de Lizardi hace evidente que las condiciones de posibilidad de la novela ilustrada en Hispanoamérica abarcan un conjunto de circunstancias complejo, que incluye la peculiar recepción local del Romanticismo y que difiere de su 
correspondiente fenómeno europeo. El ejemplo argentino se singulariza aún más: la ilustración literaria se afirma cuando un conjunto de textos claves, desde la gauchesca de Hernández hasta la narrativa expedicionaria, surge alrededor de la definitiva apropiación física y simbólica de la frontera interna nacional, planteando un problema de referencialidad y competencia visual que reclamará la presencia de imágenes. Desde Una excursión a los indios ranqueles de Lucio V. Mansilla, a La vuelta del Martín Fierro de José Hernández, hasta el ciclo narrativo indianista de Estanislao S. Zeballos, las ilustraciones estarán orientadas, en primer lugar, a representar visualmente aquellos sujetos o tipos humanos, invisibilizados en el plano de la realidad factual por la política del Estado o desaparecidos a causa de la violencia militar, como indígenas y gauchos. Las ilustraciones jugarán un papel importante en el intento de brindar a los segundos la iconicidad de un símbolo nacional y relegar a los primeros a una mera función figural, a veces a contramano de los mismos textos que acompañan. En segundo lugar, las ilustraciones contribuirán a la codificación de un paisaje nacional como escenario del drama, no sin las dificultades derivadas, por un lado, de una tradición iconográfica insuficiente y, por el otro, de una tradición discursiva romántica sobre el paisaje pampeano que los textos de los ' 70 y 180 se proponen rectificar y superar. Como se verá, la presencia de las imágenes está propiciada también por la difusión de una postura cientificista que asume cierta narrativa desde finales de los '70 en adelante. Dicha postura pretende desplazar la mirada romántica al desierto en favor de una observación naturalista y objetivista que se sirve, convencionalmente, de la imagen como complemento de la descripción.

En general, la ilustración de la narrativa hispanoamericana, a diferencia de lo que ocurre en Europa, aparece asociada a los géneros que mayormente se vinculan con las estéticas costumbristas, relacionadas también con la literatura de viajes, donde la colaboración entre escritores y artistas se hace patente. La construcción tipificadora de la nacionalidad es el ámbito en el cual se produce una integración funcional entre texto e imagen, que concurre a la codificación de tipos -figuras humanas cuyos rasgos identifican al individuo con un grupo-, escenas -es decir, instantes definitorios de un acontecer significativo-, y vistas de ciudades y/o paisajes nacionales -como construcciones identitarias espaciales (Pérez Salas, 2005a y 2005b). Más allá de la conexión inmediata y hasta banal que pueda existir entre la imagen y la creación de un imaginario nacional, cabe señalar que la interacción entre texto e ilustración afecta los funcionamientos propios de ambos códigos: el código verbal se ve afectado en cuanto a la referencialidad, pues la descripción se verá referida a la figura más que a una supuesta y aludida realidad social extratextual visualizada autónomamente por el lector. En el caso argentino que analizo, cuyas narrativas son casi todas de carácter testimonial, ese desplazamiento de la referencialidad es particularmente importante; en un texto como el de Mansilla, por ejemplo, la presencia de los retratos de 'tipos ranqueles' como referentes de las descripciones textuales, favorece una lectura distanciadora con respecto a los sujetos indígenas que emergen de la narración con marcada individualidad. El código icónico, por su parte, tendrá que negociar entre una tradición iconográfica independiente del texto y la adhesión a su propia trama descriptiva. Si bien es cierto que la ilustración literaria es un terreno de expresión más autónomo respecto de los cánones académicos, también es verdad que conlleva una convencionalidad propia del medio, inscribiéndose siempre en series iconográficas que exceden los límites de las páginas del texto ilustrado. Este punto es clave, en la medida en que las ilustraciones de las narrativas del desierto argentino tendrán que confrontarse con la pobreza del corpus iconográfico anterior a la Campaña, su recepción fragmentaria, su tardío ordenamiento, su limitada interpretación (Silvestri, 2011: 43). Contemporáneas a la emergencia del paisaje pampeano en el arte argentino (Malosetti, 2005), las ilustraciones de las novelas indigenistas de Zeballos y de la tercera edición de la Excursión, tienen que colmar un desajuste que hasta ese momento no se ha resuelto: no se trata solo un problema estético, determinado por un paisaje 
que no se adecuaba a la variedad colorística y topográfica que requerían las escuelas difundidas (Silvestri, 2011: 29), sino de un problema de percepción y de uso social de la imagen del desierto. Hasta cierto momento fue imposible ver un paisaje en la pampa, o bien, faltaba la necesidad de construirlo (Malosetti, 2005: 294). Más allá del appeal ornamental de carácter popular y comercial atribuido a la presencia de ilustraciones en la narrativa, los libros de Mansilla y de Zeballos reclaman la presencia de imágenes, y ponen de manifiesto por primera vez cierta insuficiencia de la cultura letrada en colmar un vacío de la percepción y de la representación del espacio que acaba de someterse al dominio del deseo y del conocimiento de la imaginada comunidad nacional. Las ilustraciones de la primera edición en volumen de la Excursión (1870), del Viaje al país de los Araucanos (1881), de la tercera edición de la Excursión, de la segunda edición de Relmu (1893) -pero podríamos agregar el despliegue gráfico de las ediciones gauchescas posteriores a la Vuelta del Martín Fierro (1879) y la galaxia folletinesca del populismo criollista que prolifera desde los 180 - preceden la querelle del Ateneo sobre el paisaje nacional, en 1894, en la que el campo letrado dialoga públicamente con el de las artes justamente a partir del desajuste entre las posibilidades de representación literaria y visual del desierto (Malosetti, 2001: 337 y sigs.).

A diferencia de México, cuya cultura visual tiene raíces antiguas y es terreno de conflictos cruciales para la definición de la nacionalidad (Gruzinski), la cultura rioplatense del XIX, como ha sido repetidamente demostrado, le otorga hegemonía al discurso escrito por sobre la imagen plástica, y cuenta con una limitada alfabetización visual de productores y público por lo menos durante las primeras décadas de organización nacional. En México, el costumbrismo litográfico y el costumbrismo literario ilustrado van de la mano, surgen y se desarrollan paralelamente, alimentándose mutuamente. En Argentina, los álbumes litográficos costumbristas de tipos y vistas no influyen tanto en las ilustraciones literarias, que se afirman décadas después y que se alimentan de otras series iconográficas, principalmente la pintura histórica, la fotografía etnográfica y la ilustración científica. La Conquista del Desierto coincide con la reorganización del conocimiento desde la perspectiva positivista, que afecta de manera decisiva la cultura letrada y favorece la práctica de la ilustración: puede decirse que la gran eclosión de la cultura visual se da con el desarrollo de los intereses científicos y su divulgación. La descripión naturalista y geográfica, campo regido por la idea de conocimiento científico promovida por Humboldt, entre fines del siglo XVIII y primera mitad del XIX, contaba con la estricta colaboración entre científicos y artistas, y constituye un antecedente clave de las ediciones ilustradas de fines de siglo XIX. Las litografías sacadas de las fotos de la campaña científica de Zeballos, que acompañan su Viaje al país de los araucanos, de 1881, y las litografías que ilustran la Excursión en la edición de 1890, impresas dentro del Museo de Ciencias Naturales de La Plata, son un testimonio elocuente de esa filiación.

Me limitaré al análisis de los libros mencionados más arriba, considerando la Excursión de Mansilla y los textos de Zeballos, como pertenecientes a un mismo corpus narrativo ilustrado que da cuenta de lo dicho anteriormente acerca de las circunstancias motivadoras de la irrupción de la imagen en la edición literaria argentina. ${ }^{4}$

Tras su primera publicación en entregas para La Tribuna de Buenos Aires, Una excursión a los indios ranqueles conoce en el plazo de 20 años tres ediciones autorizadas por el autor, de las cuales dos ilustradas. Su historia editorial coincide, pues, con el cambio radical que la Conquista del Desierto produce en la realidad representada en el libro, y también con el cambio de paradigma en los discursos en torno a la cuestión indígena. Las ilustraciones permiten rastrear mejor que cualquier otro peritexto los cambios de posicionamiento del texto del Mansilla en el horizonte de experiencias y expectativas que determinan su recepción, y con ella su sentido, históricamente determinado por la lectura.
4. Para el caso de la Excursión, me permito sintetizar aquí algunos de los comentarios ya publicados en otro artículo (Salvioni, 2015) y actualizados en ocasión del Congreso del Celheis de Mar del Plata en 2017. 


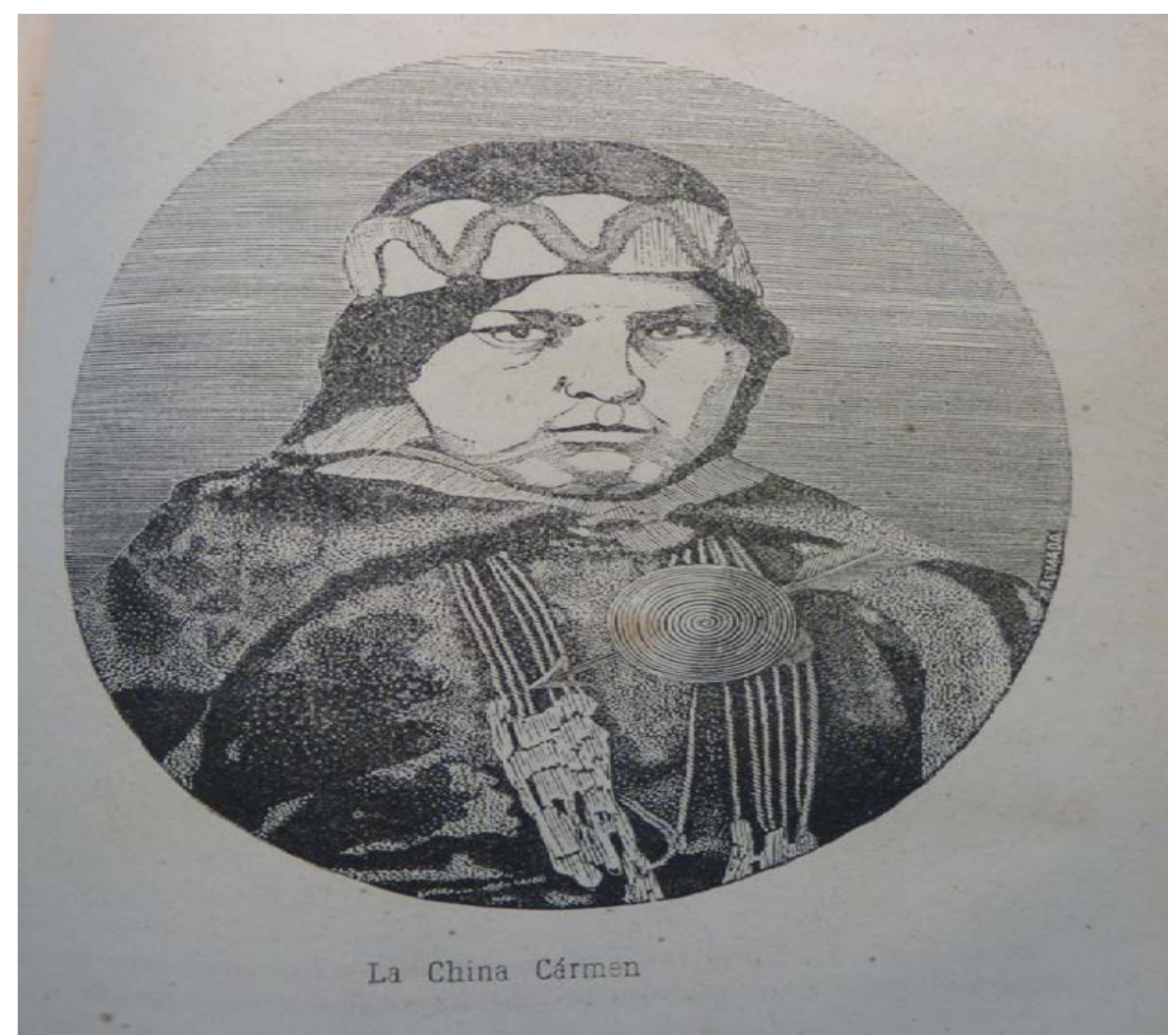

Para la edición de 1870 se imprimen cinco retratos grabados por el artista Lázaro Almada, de los cuales uno es de Mansilla, dos son personajes ranquelinos del texto (Caiomuta y la china Carmen) y dos son "tipos" indígenas ("Tipo de mujer ranquelina" $y$ "Cacique ranquel vestido de parada"). Almada trabaja a partir de fotografías etnográficas, valiéndose de las que empezaban a producirse en la década del 1860. Inaugura, de esa forma, un procedimiento que caracterizará la práctica de la ilustración en la Argentina, por lo menos en el corpus que tomo aquí en consideración. Evidentemente, la fotografía constituye un recurso clave para resolver el primero de los problemas de representación planteados por el texto de Mansilla, es decir, el modelo o serie iconográfica en la que inscribirse a la hora de sugerir una imagen plausible no solo del indio en tanto referente extratextual, sino de una otredad tan contradictoria como la que está enunciada en el texto de Mansilla. La serie pictórica y litográfica sobre los pueblos originarios de los territorios nacionales no constituía un modelo funcional a la hora de ilustrar el libro. Tal como la reconstruye Bonifacio del Carril, parece una serie tan exigua como poco instalada en el imaginario colectivo. Por otra parte, cuesta acercar visualmente los indígenas de Rugendas, los aucas de Parchappe, o los pampas de Pellegrini o de Morel, a los ranqueles de Mansilla, retratos vívidos y fuertemente individualizados de una realidad transculturada, sujetos de una expresividad articulada en mil matices. En este sentido, la aparición de la fotografía etnográfica constituía sin duda un recurso que, tal como el texto de Mansilla, brindaba la ilusión de una objetividad testimonial de alguna forma inédita. Almada elabora las fotografías sin fondo ni elementos de contexto, y posiblemente las retoca en función de las descripciones brindadas por Mansilla en lo que concierne las vestimentas y adornos de los personajes. Por otra parte, las fotografías etnográficas de la década del 6o, que pudieron estar a disposición de Almada, ofrecen escasa o ninguna manipulación de vestimenta o de pose por parte de los retratistas (Giordano, 2011: 9). Los indios sostienen, en ellas, una postura firme, mirando fijo a la cámara, que responde a la condición de libertad y autonomía de los sujetos indígenas, reflejada en la postura hierática de las ilustraciones de Almada. En éstas, los sujetos aparecen 


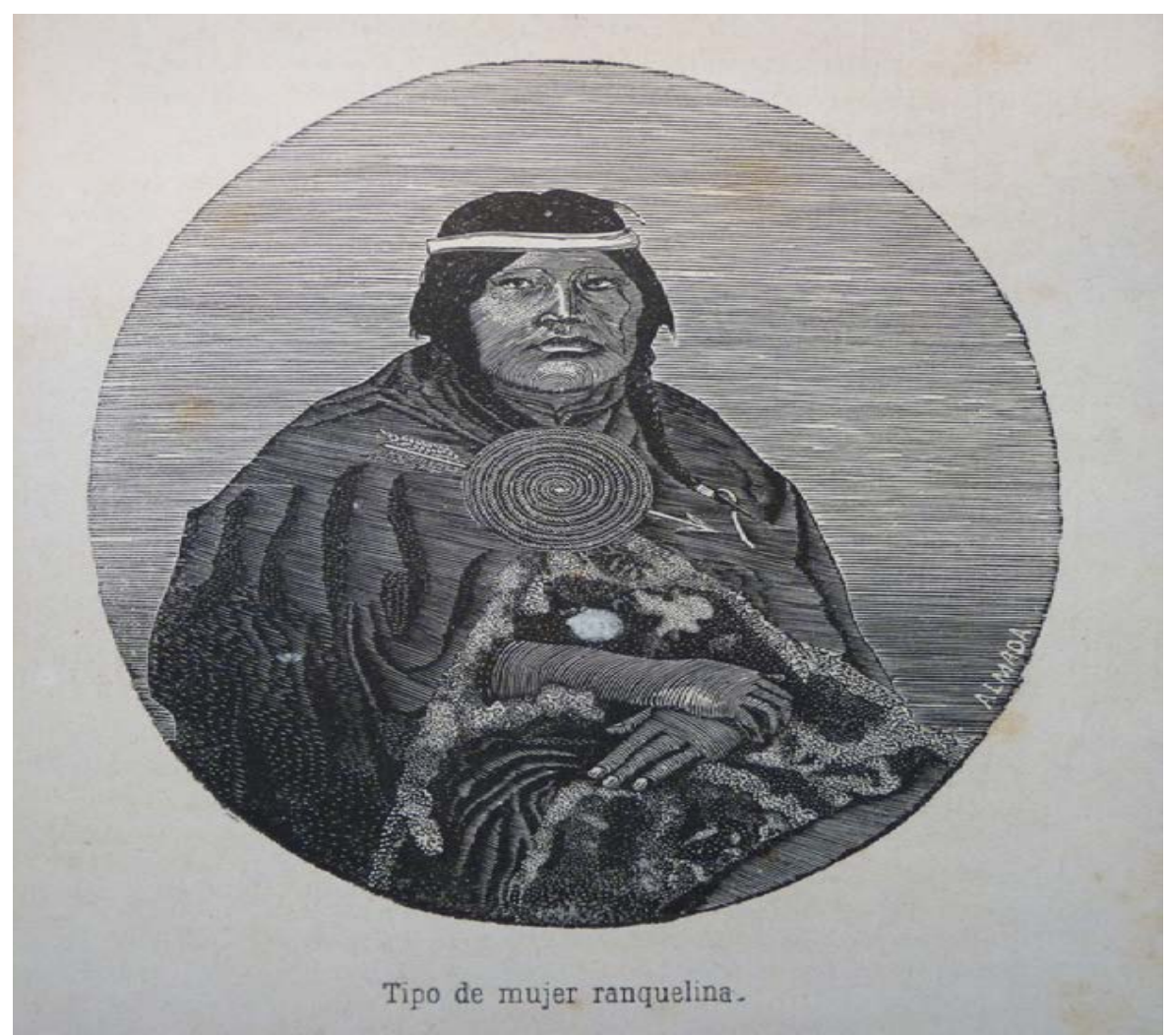

de frente y completamente estáticos, como pretendiendo condensar en el dato visual del retrato una totalidad evocada por el texto, pero sin poder adoptar el punto de vista próximo y móvil de su enunciador. Puede decirse que los grabados de Almada oscilan todavía entre la tentativa de retratar a los personajes del libro y la explícita tipificación del indio ranquel -como demuestra la escasa o ninguna diferencia que hay entre el retrato de la "China Carmen", por otra parte, uno de los pocos personajes del texto del que Mansilla no brinda ninguna descripción física, y el "Tipo de mujer ranquelina", que en cuanto al atuendo y adornos funciona como compendio de los personajes femeninos evocados en el texto (fig. 1 y 2)-, una tipificación destinada a acentuarse en las ilustraciones de las ediciones posteriores a la Campaña.

En la edición de 1890, mucho más esmerada tipográficamente, las ilustraciones están a cargo de José Bouchet, pintor afirmado en el género histórico, quien recibe el encargo de la editorial de Juan A. Alsina mientras trabaja en la decoración de la rotonda del Museo de Ciencias Naturales de La Plata, donde materialmente se imprimirán las litografías. El libro de Mansilla entra, de esa forma, metafórica y concretamente en el museo, el mismo que acogerá los restos mortales de Mariano Rosas, para ser asimilado a la narración que subyace al coleccionismo científico y a la museología etnográfica de fin de siglo, que tiende a borrar el sujeto real y construir en su lugar una imagen.

Bouchet, al igual que Almada, procede a la elaboración de retratos a partir de fotografías. Para eso, puede recurrir a un repertorio de imágenes mucho más variado, y profundamente distinto en sus características intrínsecas respecto del repertorio de los 6o. Después de la Campaña al Desierto, la circulación de imágenes de indígenas se hace más profusa, ya sea en álbumes, postales, revistas ilustradas o exposiciones en museos. Los 'indios' se vuelven, así, un objeto visual coleccionable. De alguna manera, la 'competencia visual' de los lectores de la Excursión ha evolucionado, sin que eso implique un avance en el conocimiento de la realidad indígena. Las fotografías que Bouchet encuentra cómodamente expuestas en las salas del museo donde está trabajando, son imágenes precedidas por 


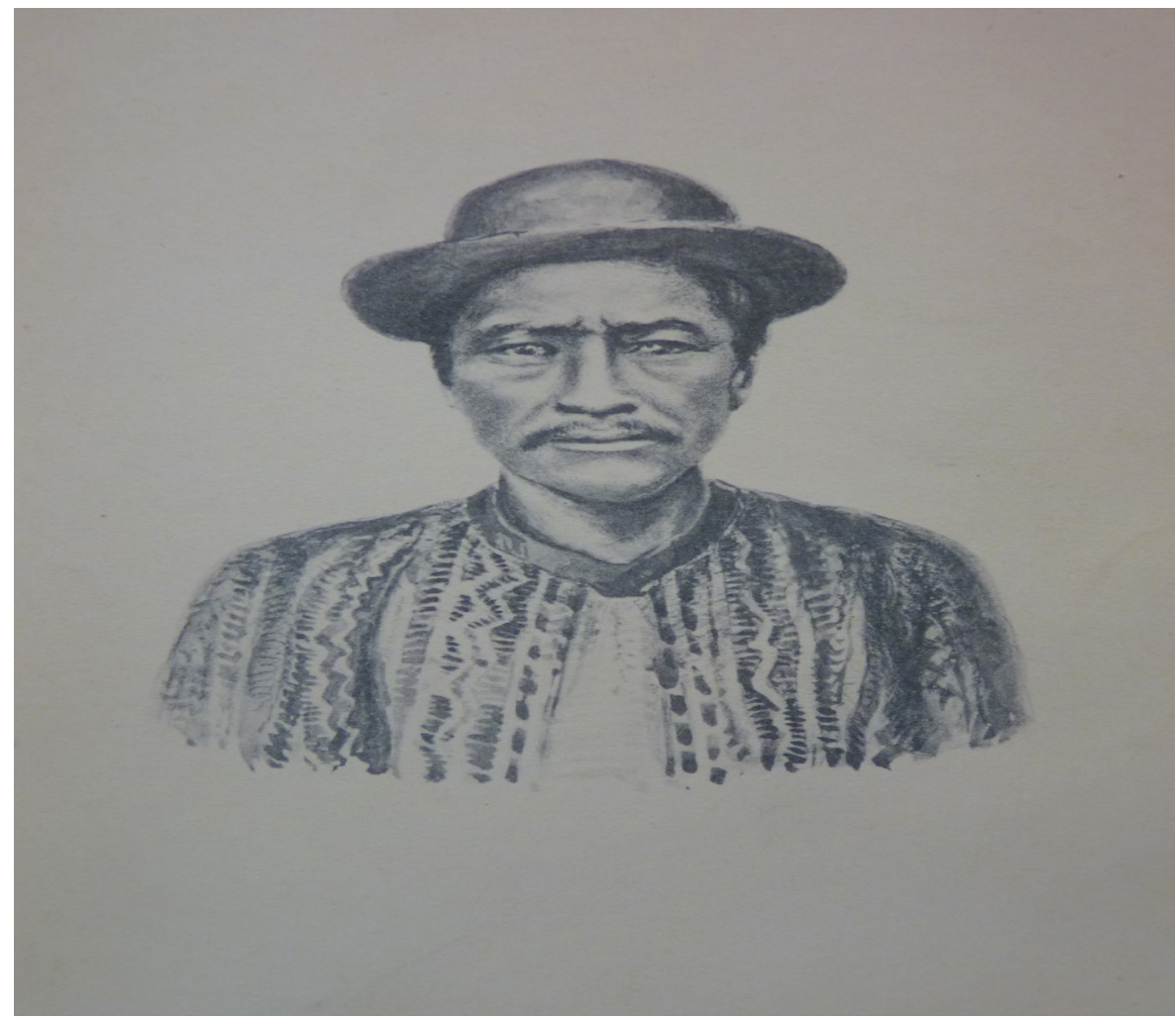

el concepto: manipuladas en las poses, la vestimenta, la composición y los elementos de contexto, para que respondan a un horizonte de expectativas exóticas, que relega al indio al pasado premoderno del país, negándole su contemporaneidad. Estas fuentes visuales de segundo grado contribuyen a distanciar el relato de Mansilla de su inmediata referencialidad temporal: la Excursión ha dejado de ser un reportaje ante litteram sobre la estricta actualidad nacional, para convertirse en narración de un recuerdo ya lejano. Las "falacias iconográficas" evidenciadas por Vignati (1947), quién rastrea las fuentes fotográficas de los retratos de Bouchet demostrando que no corresponden a sujetos del grupo ranquelino conocido por Mansilla, sino a la familia de Manuel Namuncurá, ponen de manifiesto cómo el ilustrador de la Excursión prescinde de la concreta individualidad de los indígenas, ya sea en tanto sujetos históricos, ya sea en tanto personajes del relato, como demuestra, por ejemplo, el retrato de Mariano Rosas, que no conserva ni un rasgo de la caracterización del personaje proporcionada por el texto (fig. 3):

Una negra cabellera larga y lacia, nevada ya, cae sobre sus hombros y hermosea su frente despejada, surcada de arrugas horizontales. Unos grandes ojos rasgados, hundidos, garzos y chispeantes, que miran con fijeza por entre largas y pobladas pestañas, cuya expresión habitual es la melancolía [...]; una nariz pequeña, deprimida en la punta [...], una boca de labios delgados, que casi nunca muestra los dientes [...]; una barba aguda, unos juanetes saltados [...] y unas cejas vellosas arqueadas [...] (Mansilla, 1947: p.180)

Los retratos de Bouchet, quien retoca las fotografías modificando las vestimentas sin propiciar por eso una similitud con las descripciones de Mansilla, marcan una distancia con lo narrado mucho mayor de lo que ocurre con las ilustraciones de Almada.

Pero la mayor novedad de las ilustraciones de Bouchet son las láminas que representan escenas, y precisamente dos cuadros de vida indígena, que reproducen los óleos pintados por Bouchet en el Museo de la Plata, que no tienen correlación directa con 


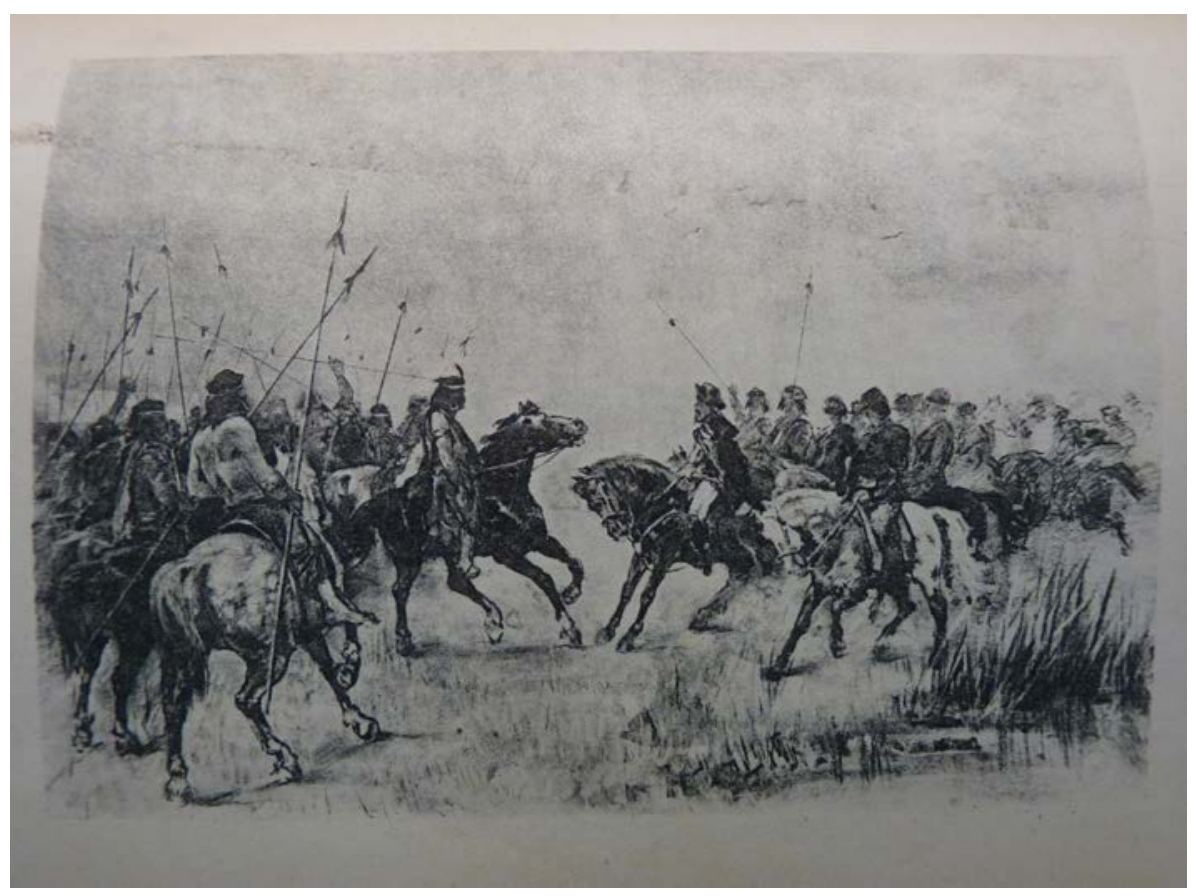

Figura 4

el texto, y cuatro ilustraciones de anécdotas sobresalientes del relato. El ilustrador selecciona los pasajes del texto que aluden al encuentro con los ranqueles, empezando por el primer contacto visual, el "Indio bombero", para luego seguir con escenas que presuponen una interacción directa del protagonista Mansilla con los indios, en "La topada", "Los abrazos" y "El parlamento". Sin poder inspirarse en el modelo fotográfico, Bouchet muestra aquí cierta dificultad en brindar una imagen plausible de los ranqueles, que de hecho aparecen de espaldas y de costado, o apenas estilizados en grupos humanos compactos en los que las facciones individuales aparecen desdibujadas. Los ranqueles actúan dentro de un esquema ordenado y convencional, sin dejar lugar a los enigmas y contradicciones presentes en el relato de Mansilla. A nivel de las composiciones, las ilustraciones retoman la disposición clásica de la pintura de batalla o de tema histórico (Bouchet se había formado en el taller de Juan Manuel Blanes), dibujando siempre los dos grupos -los ranqueles y los miembros de la expedición del coronel Mansilla- dispuestos en bandos enfrentados y perfectamente simétricos, ocupando el espacio en un juego de llenos y vacíos que no deja lugar a la desarmonía, sino que parece aludir a un código bélico protocolario y convencional, o quizás, a una ideal recomposición del conflicto y de la violencia de la conquista. "La topada" ilustra el primer contacto verbal entre la delegación militar argentina y los dignitarios del cacique, que se produce con la complicada mediación de intérpretes y delegados, obedeciendo a las reglas de la oratoria ranquelina. Si la narración del encuentro se dispara en mil desopilantes digresiones que imitan la inagotable oratoria indígena, sus giros lingüísticos, numeraciones, recaudos, protocolos enigmáticos, exhibiendo un desorden expositivo que contribuye a la desarticulación de la simetría dicotómica sarmientina, la escena ilustrada se cristaliza en un momento ceremonioso y se recompone en un equilibrio clásico. En el centro, las cabezas de los caballos se disponen de manera tal que permiten el acercamiento de los jinetes sin estorbarse, formando un arabesco; del lado de los blancos, el pastizal rellena el vacío causado por el número menor de hombres a caballo respecto al grupo de indígenas, salvando la simetría (fig. 4).

En "El parlamento", que representa el clímax del relato, es decir la junta celebrada con caciques y capitanejos ranqueles para la ratificación del tratado de paz, parece 


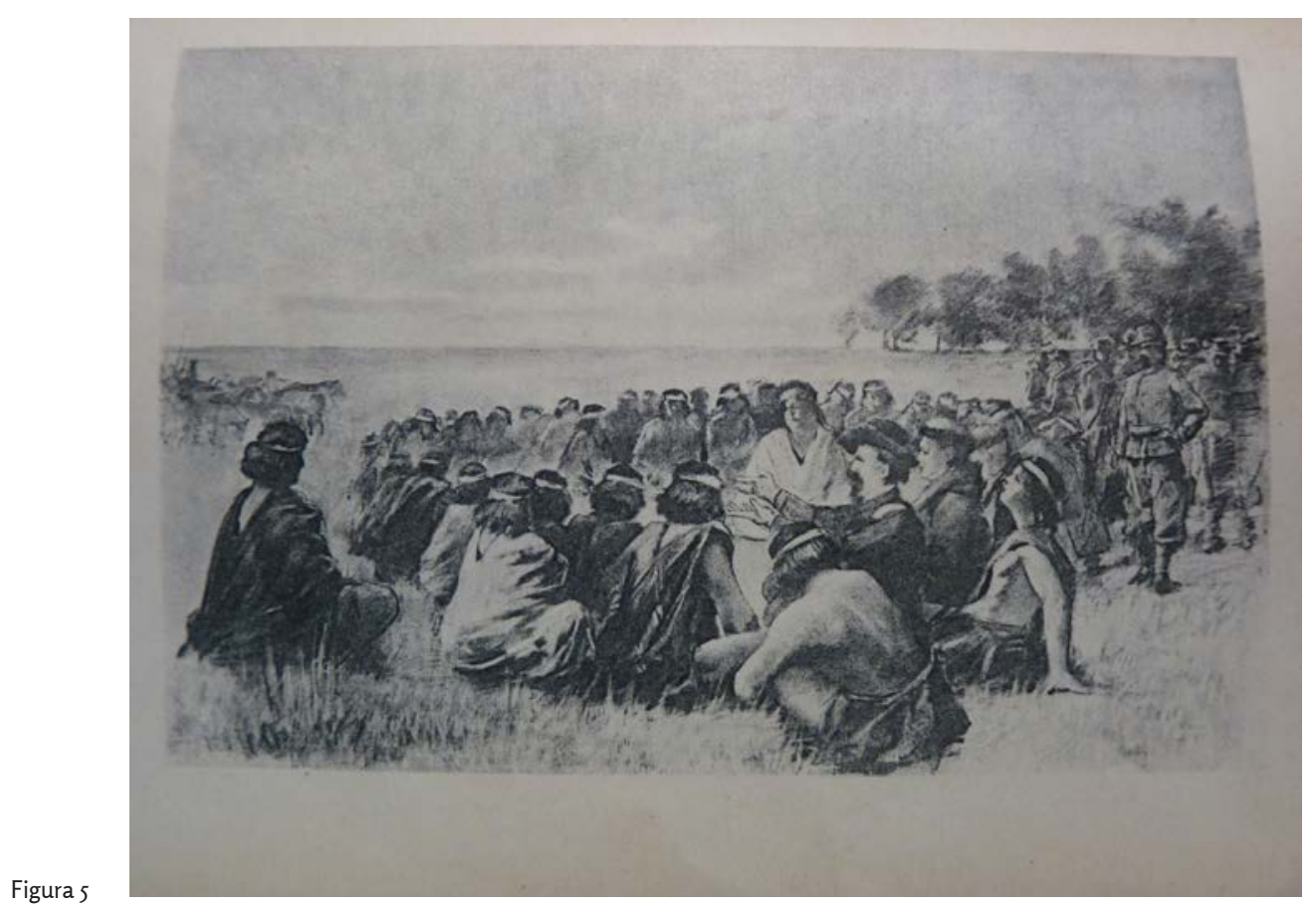

cumplirse la neutralización del desorden presente en el texto. En éste, la junta es el momento en el que las voces de los indios emergen con mayor claridad, aún en el barullo general. La ilustración de Bouchet recompone la pluralidad de las voces indígenas en un esquema compositivo circular, que inscribe la escena representada en la totalidad armónica de un universo geográfico y humano cerrado e ideal. En ese conjunto, Mansilla, sentado frente a las figuras desdibujadas de sus oyentes, aparece como el único orador; su presencia imponente parece incluso conducir a un error de la perspectiva circular, donde el perfil del coronel resulta desproporcionadamente grande, como dirigiéndose a un auditorio situado fuera del círculo (fig. 5).

En cuanto al paisaje, Mansilla procede en el texto con descripciones que tienden a la rectificación de la tradición poética sobre la pampa, en abierta contradición con el paisaje sarmientino y con la visión romántica. Se propone, entonces, una misión rectificadora de dicha tradición que contrapone el "paisaje ideal", definido por su perfecta horizontalidad sublime y terrorífica, con un "paisaje real", que conduce al desencantamiento del Desierto en pos del Progreso:

Los que han hecho la pintura de la Pampa, suponiéndola en toda su inmensidad una vasta llanura, jen qué errores descriptivos han incurrido! Poetas y hombres de ciencia, todos se han equivocado. El paisaje ideal de la Pampa, que yo llamaría, para ser más exacto, pampas, en plural, y el paisaje real, son dos perspectivas completamente distintas (Mansilla, 1870: 103).

Bouchet, en cambio, opta por atenerse a las convenciones hasta ese momento codificadas en la representación del ambiente pampeano: el punto de vista bajo, que deja lugar a la puesta en valor del cielo, muchas veces atravesado por las lanzas indígenas que marcan una verticalidad compensadora de la llanura, y la construcción del espacio en función de la acción y de los personajes que se mueven en él.

En conclusión, las ilustraciones no pueden, en ningún momento, dar cuenta de esa dimensión tan propia de la prosa de Mansilla -sus desplantes irónicos, su lógica 
digresiva, sus ambiguos ideologemas-, que constituye también la cifra de la distancia entre la Excursión y otros textos aparentemente cercanos por temas y circunstancias, como los relatos de viaje al desierto de Estanislao Zeballos.

Tras su primer bestseller oficial, La conquista de quincemil leguas (1878), Estanislao S. Zeballos se especializa en una escritura híbrida, científica, divulgativa, utilitaria y literaria, con fuertes acentos pragmáticos y casi performativos, en el sentido de que pretende actuar dentro de la realidad que representa y de la que forma parte. Esos "apuntes sobre los antecedentes de la ocupación de Río Negro" se ofrecen a los jefes y oficiales del ejército expedicionario para proporcionarles "un conocimiento sintético de la obra en que van a colaborar" (cit. en Torre, 2010: 53), afirmación que no deja de ser ambigua en cuanto a la noción de "obra", ni de complicar las relaciones de causa/efecto entre la escritura/lectura del propio texto, el conocimiento del medio y la conquista. Ahora bien, si puede llegar a comprenderse que La conquista de las quincemil leguas se publicará a expensas del Estado argentino para ser distrubuido entre a los oficiales del ejército, menos explicable es que se siguieran publicando durante décadas, en la Biblioteca del Suboficial, novelas como Relmu, la princesa de los pinares, del mismo autor. Lo cierto es que Zeballos se va perfilando, desde finales de los '7o hasta el fin del siglo, como auténtico experto y sostenedor de la 'conquista epistemológica' del Desierto, abordado desde distintas perspectivas integradas, cuyo conocimiento se basa tanto en el trabajo de archivo como en el viaje científico a los territorios recién conquistados. Pocos años después, en 1881, Zeballos publica Viaje al país de los araucanos, el primer tomo de una trilogía dedicada a la Descripción amena de la República Argentina en su totalidad. La trilogía hubiera tenido que empezar con el tomo dedicado al Litoral, El país del trigo, pero el autor decide invertir el orden, consciente de que "se abre recién a las miradas de la Ciencia el vasto y misterioso territorio, que nombrábamos y describíamos con la palabra pampa, y que acabo de cruzar" (Zeballos, 1881: VI). Zeballos emprende el viaje a ese "vasto y misterioso territorio" armado de libros en blanco para llenar, cada uno desde una perspectiva distinta: impresiones y descripción física del territorio, observaciones meteorológicas, diario de mensura, diario de marchas, diario topográfico, libro de paisajes, libro de correspondencia (Zeballos, 1881: 123). Tal es el filtro cientificista que el viajero aplica a sus observaciones, con la intención de brindar una descripción "amena", abordable narrativamente, de la nueva geografía nacional, matizando sus "especulaciones literarias" con "un tinte científico" (Ibídem). Esta multiplicidad de enfoques está rerpesentada gráficamente por la lámina que abre el volumen, que retrae al propio autor en el entorno natural de Quethé Huithú, rodeado de los atributos que constituyen su equipaje al emprender la excursión científica: un caballo, que alude al movimiento de la marcha a través del territorio, motivo estructurante de la narración; una caja de instrumentos científicos aptos a la mensura topográfica, filtro para la aprehensión técnica y utilitaria del terreno; un libro abierto, representación de la escritura misma del texto; una calavera de indio, que remite al coleccionismo de restos antropológicos, gran afición de Zeballos, que confluirá en los museos etnográficos de la época; y una cámara en su trípode, que alude al procedimiento de ilustración de la obra, cuyas litografías proceden en su gran mayoría de las fotografías tomadas durante el viaje por el fotógrafo acompañante de la expedición, después de que las placas fotográficas se revelaran inadecuadas para ser publicadas. Zeballos aludirá en muchos pasajes del texto al origen fotográfico de las ilustraciones, como medio de validación de su testimonio, cuya objetividad estaría garantizada justamente por esa imagen inicial de la cámara sin operador (Silvestri, 2011: 218), aunque el fotógrafo de la expedición actúe frecuentemente como personaje en el texto.

Viaje al pais de los araucanos mantiene una estricta relación intertextual con la Excursión de Mansilla, con la que coincide en parte de su recorrido físico por la 


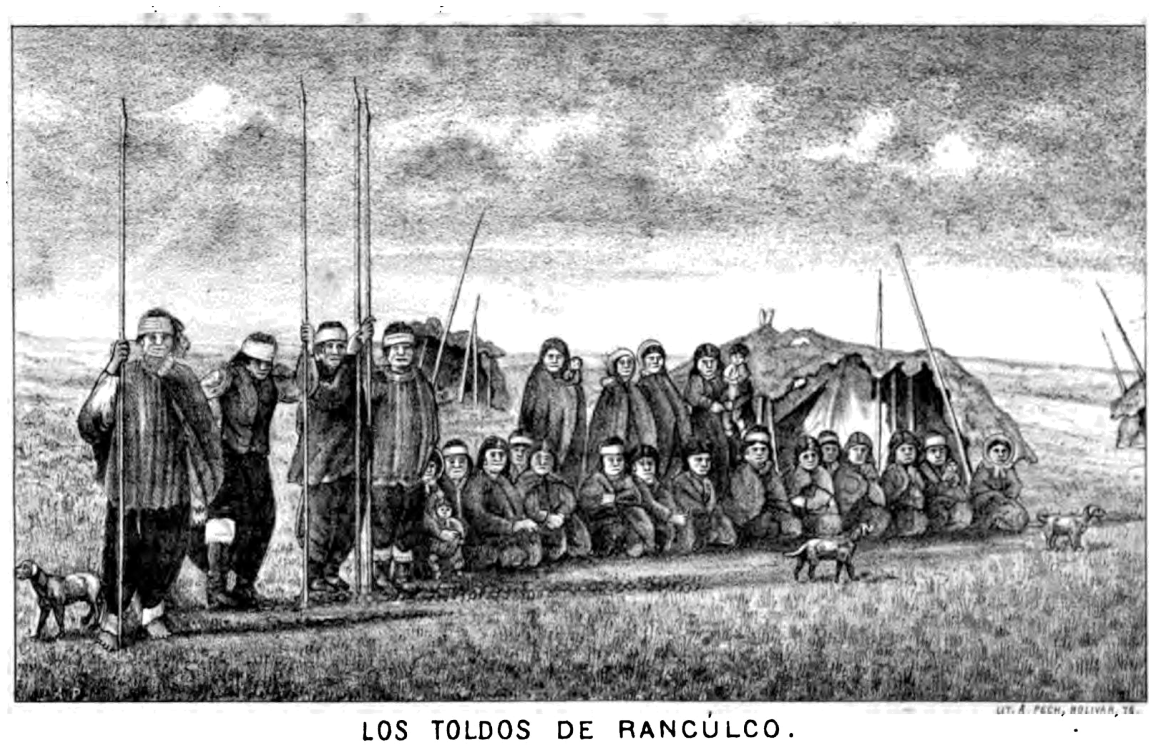

región pampeana. El hipotexto emerge más de una vez: de forma implícita, como en la apología del caballo pampeano (Zeballos, 1881: 173) que recuerda pasajes similares de Mansilla, o la admirada descripción sobre el arte de encender el fogón sin leña a la vista (175), también presente en la Excursión; de forma explícita, con el epígrafe a la segunda parte del libro, "Causas y teorías", que retoma el lema de Mansilla: "No puedo hablar como un sabio: hablo como un hombre observador", particularmente significativo, pues en la autorepresentación de Zeballos las dos figuras -el sabio y el observador- coinciden perfectamente.

A pesar de que Zeballos declara no querer detenerse en la descripción etnográfica -"Omito todo estudio etnográfico en este tomo, ya que consagraré uno enteramente a la raza araucana" (Zeballos, 1881: 193)-, algunas de las ilustraciones se refieren a los indígenas con los que el viajero interactúa. Entre las láminas etnográficas destaca "Los toldos de Ranculco", cuya génesis está narrada con detenimiento en el texto. El episodio referido gira justamente en torno al intención de Zeballos de fotografiar la toldería del cacique Quiñelev, a dos kilómetros de Lavalle. En la descripión, resuenan algunos tópicos de las descripciones de Mansilla (la jauría de perros hambrientos, la actitud pedigüeña de los indios), aunque en Zeballos aparecen despojados de la ironía y desparpajo con que se despliegan en la Excursión. Rebosan, en cambio, de un desprecio inequívoco derivado de la mirada científica y medidora del viajero: "Las estaturas de esos personajes, que medí, dieron: - Quiñelev, $1^{\mathrm{m}} 55$, Chipitruz, $1^{\mathrm{m}} 50$, Maldonado, $1^{\mathrm{m}} 58$. ¡Vaya unas fachas de soberanos!" (Zeballos, 1881: 71). Zeballos demuestra hacia los seres humanos la misma obsesión para la medición y la fotografía que dirige al paisaje, y trata de convencer a la tribu mediante engaños para que se someta a ambas operaciones. La negociación lleva un tiempo, durante el cual el fotógrafo prepara los instrumentos de captura fotográfica, cuyo aspecto amenazador, percibido por los indios, se refleja oscuramente en la retórica de la narración: "La fotografía, cámara oscura y laboratorio estaban armados sobre la pampa, como el cañón con la mecha puesta" (Zeballos, 1881: 72). Cuando la tribu accede al pedido de Zeballos, alineándose fuera de los toldos para la toma, la mirada converge rápidamente al componente femenino, sopesado con criterios estéticos, antropométricos y hasta utilitarios:

Aquellas mujeres llamaban la atención no precisamente desde el punto de vista estético, porque [...] carecen de rasgos completos y bellos. [...] pero sus tristes ojos [...] les dan un aspecto que atenúa el efecto de las deformaciones óseas (Ibídem). 


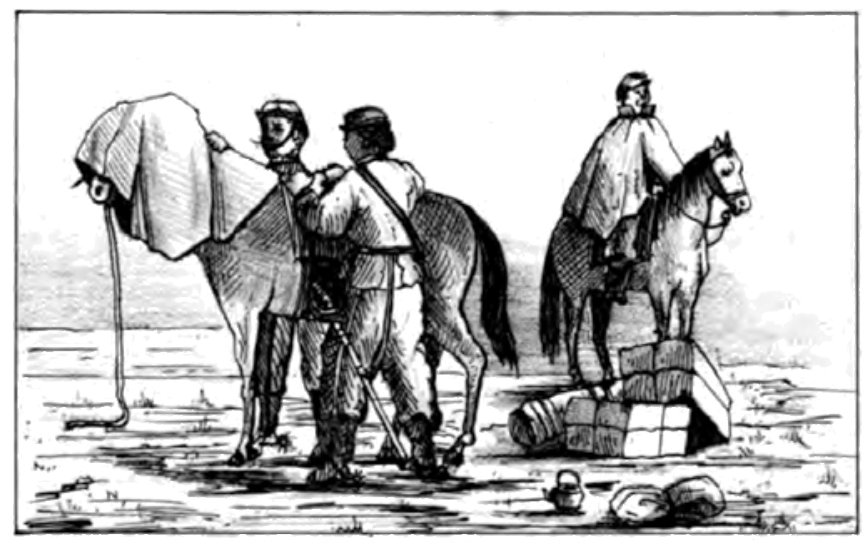

ARREGLO DE UNA CARGA.

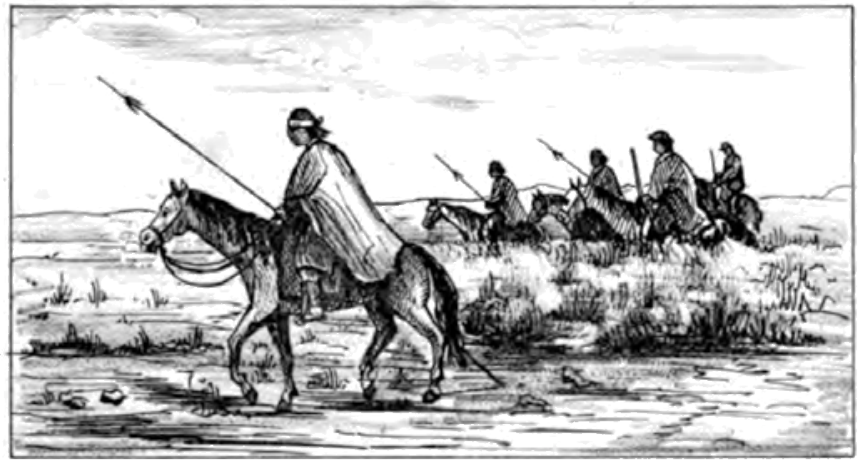

PANCHO FRANCISCO

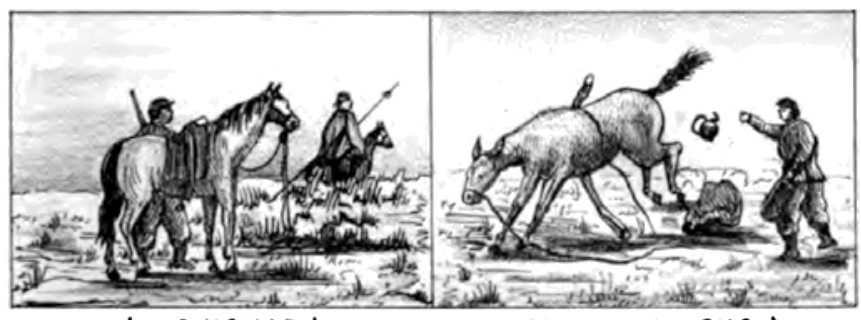

I A CINCHAR!

MA...A.... CHO !.

Si el examen puramente estético, es decir la búsqueda de la simetría propia de la belleza ideal, resulta negativo a causa de una cefalometría defectuosa, el siguiente cambio de perspectiva, esta vez funcional y utilitaria, deja lugar a apreciaciones veladamente deseantes. Cuando el estado de naturaleza atribuido al indígena se refiere a la mujer, se establece la comparación con la mujer blanca y civilizada, que revierte las consideraciones morfológicas a favor de las mujeres bárbaras, cuyos bustos no han sido deformados por el corsé:

Revelan esas mujeres una constitución física vigorosa y sana [...] Todas son gruesas, sin llegar al estado epidémico de obesidad común en la mujer argentina, y como una rareza se ven allí esas débiles criaturas devoradas por el histerismo ó por la tisis. Brazos llenos, bien contorneados, piernas derechas, talle mediano, y cierta elegancia en el cuerpo con naturalidad y gracia en los contornos primitivos, que el corsé no ha deformado. (Ibídem)

Finalmente, se produce la toma fotográfica, después de vencer las últimas resistencias, cuyo resultado es anunciado triunfalmente por el narrador: "La lámina titulada Los toldos de Ranculcó es el fruto de esta laboriosa escena” (Ibídem). La litografía de A. 


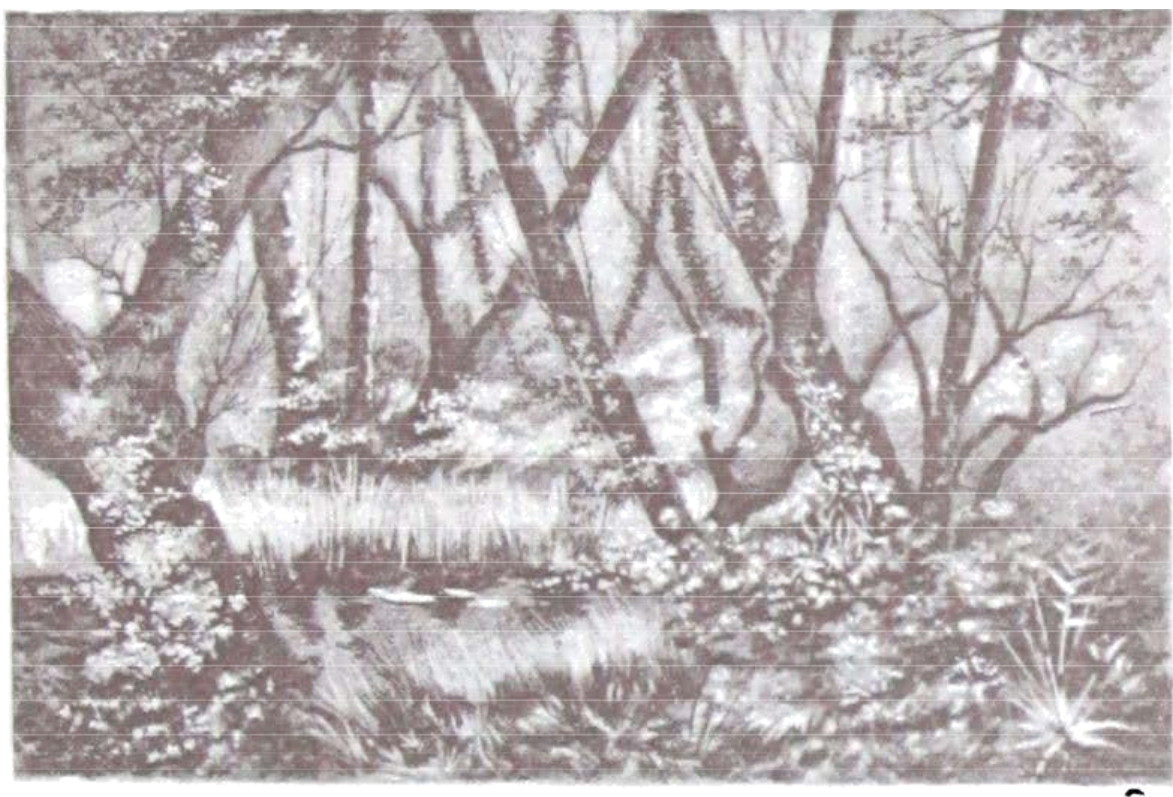

Pech revela un grado elevado de elaboración gráfica en los rostros, cuya definición fotográfica debió ser decepcionante, y que están uniformados por facciones estilizadas (fig. 6).

Ese tipo de glosa acerca del origen o del significado de las láminas es frecuente en el texto, tanto que la propia narración se define a menudo en relación con las ilustraciones, en forma de comentario, explicación o reconstrucción de la escena representada, recuperando así, en el mensaje verbal, la diacronía que la imagen fatalmente no puede reflejar. Esa estricta interacción entre texto e ilustración es consustancial al género narrativo expedicionario, ya que deriva del gesto ostensivo que dicho género presupone: mostrar lo que el narrador/testigo dice haber visto en la Tierra Adentro, ese espacio ocultado a los ojos del lector implícito, blanco y urbanizado, que necesita ser puesto a la vista, enseñado.

Las únicas litografías que no derivan de fotografías son las que ilustran escenas en movimiento de la vida pampeana, como en el caso de las láminas: "Arreglo de una carga", "Pancho Francisco" y "A cinchar... maacho!". Una vez más, las ilustraciones son precedidas, en la diagramación de las páginas, por la extensa explicación de las escenas, introducidas por una breve presentación: "Entre las láminas de este capítulo hay dos que espresan á lo vivo una de las escenas ordinarias en que las mulitas desempeñan su papel" (Zeballos, 1881: 240). La secuencialidad de la narración está salvada por el formato de las tres viñetas consecutivas, que reproducen el movimiento de la operación de carga. Esas láminas narrativas son claramente herederas de las litografías costumbristas de las décadas anteriores (fig. 7).

Poco depués de la Descripición amena, Zeballos publica el ciclo narrativo indigenista que incluye Callvucurá y la dinastía de los piedra (1884), Painé y la dinastía de los zorros (1886) y Relmú, reina de los pinares (1888), como parte del mismo proyecto de aprehensión cabal y ecléctica de la realidad nacional, esta vez desde la escritura literaria, o bien, la historia étnica novelada. La segunda edición de la novela Relmú, de 1893, se publica ilustrada con fotograbados realizados por Jacobo Peuser a partir de dibujos originales de Martín Malharro.

El rol de Malharro en la definición del campo artístico en la Argentina y su posición como innovador del lenguaje, entre fines del siglo XIX y principio del XX, ha sido 


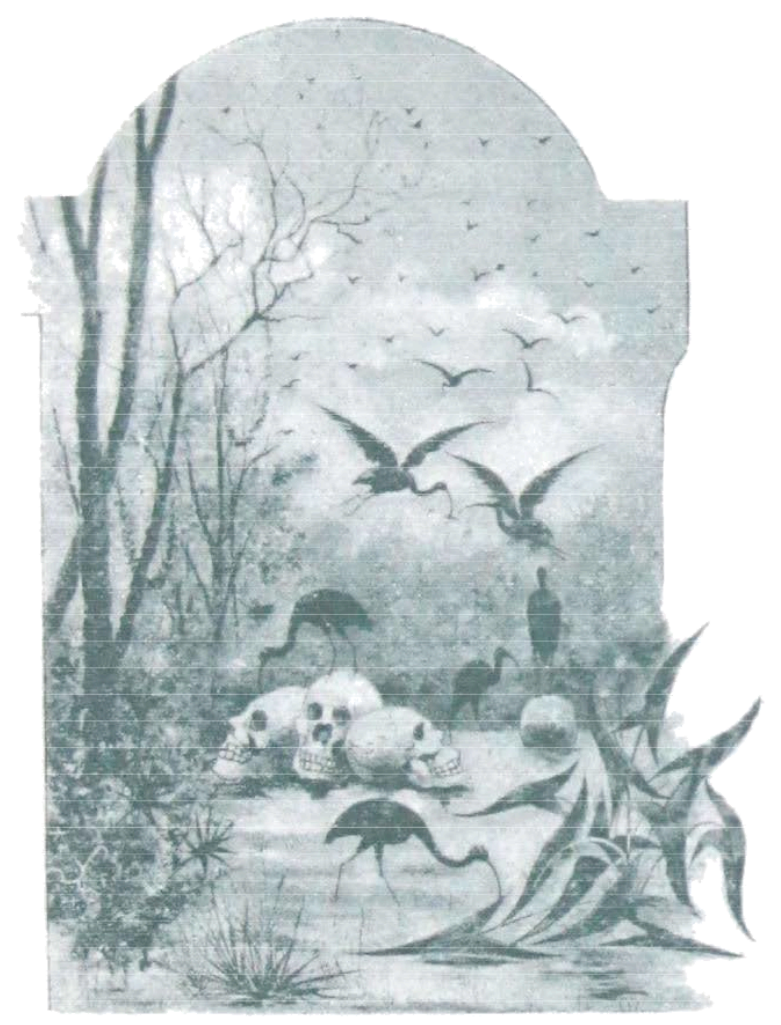

ampliamente estudiado (Wechsler, 2001, Malosetti, 2008). Cabe aquí señalar que su acostumbrada actividad de ilustrador en la prensa periódica y en la editoría encuentra, en la novela de Zeballos, un terreno propicio para el ensayo del tema que caracterizará sus investigaciones plásticas, sobre todo después de su viaje a París, en los primeros años del nuevo siglo: el tema del paisaje nacional.

Si la Descripción amena constituía el intento de representación del paisaje desde una perspectiva geográfica, con todos los tecnicismos del viaje científico, en Relmu Zeballos podía finalmente transformar el terreno que había visitado, estudiado, medido y fotografiado, en el escenario de un drama que remitía a los antecedentes históricos de la Campaña al Desierto, en época de Rosas. Respecto de las primeras dos novelas de la trilogía, en Relmu prevalece el elemento puramente ficcional y sentimental, dentro de una trama histórica que se refiere al juego de relaciones y alianzas de las poblaciones indígenas en los enfrentamientos entre federales y unitarios. Destaca la dramatización del paisaje, que se realiza con el intento de representar el movimiento de los personajes, una pareja de cautivos fugitivos, a través de los distintos territorios indígenas, ya protagonistas del Viaje al país de los araucanos, desde las selvas y las sierras precordilleranas, al desierto de Leubucó. Precisamente esta variedad de paisajes le permite a Malharro ensayar la representación del espacio nacional fuera de los clichés frecuentes hasta ese momento. Por otra parte, la historia que se desarrolla en la novela le ofrece la oportunidad de proyectar el drama humano de forma simbólica en los entornos naturales representados, convertidos en correlatos objetivos de los sentimientos y emociones suscitados por el drama identitario que se produce en el relato. El bosque en el que empieza la marcha desesperada de los dos fugitivos, el joven Liberato y la ex cautiva Panchita, se describe en el texto con todos los atributos de un caos primigenio en el que reina el desorden, aunque en él es posible vislumbrar rasgos de una belleza pintoresca: "El paisaje era, en verdad, abigarrado, pero hermoso" (64). En la ilustración correspondiente, ese espacio a la espera de una instancia ordenadora que le brinde sentido, se representa como una red tupida de troncos y 


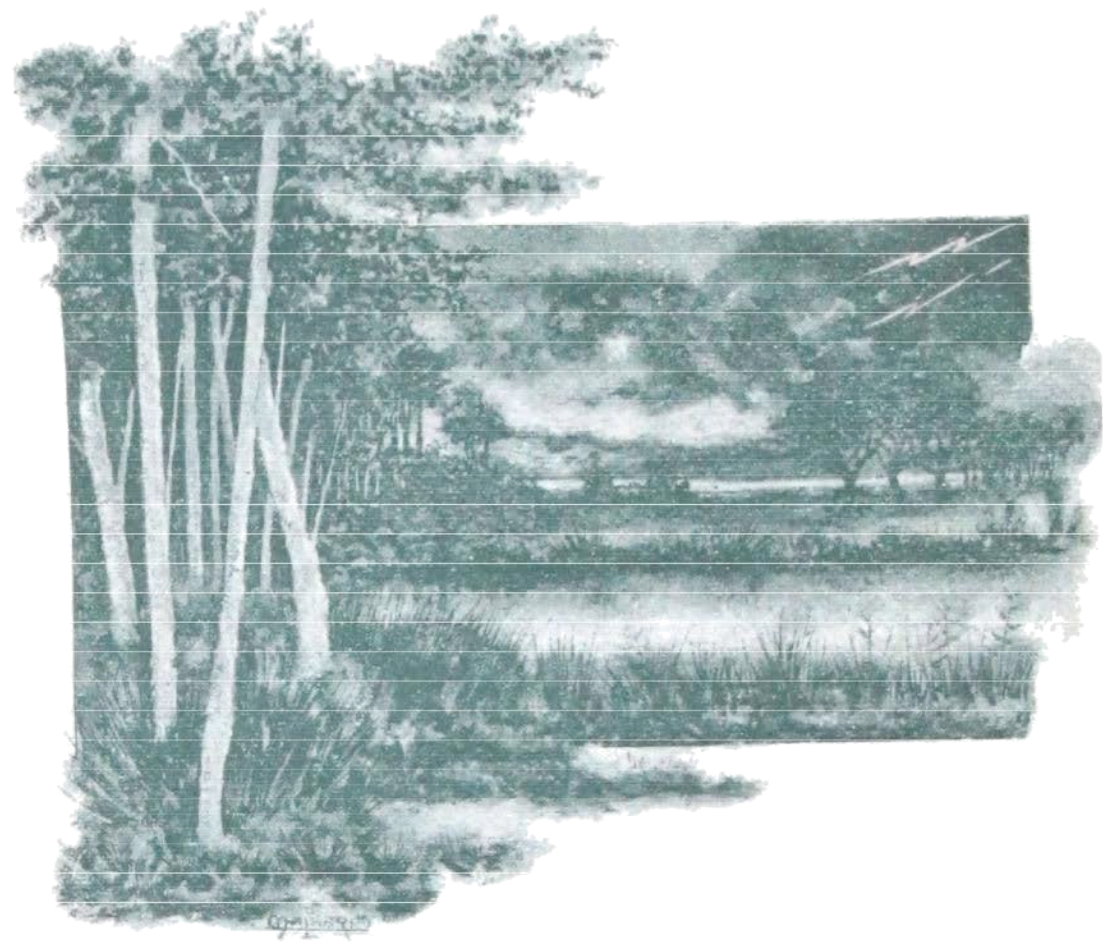

Figura 11

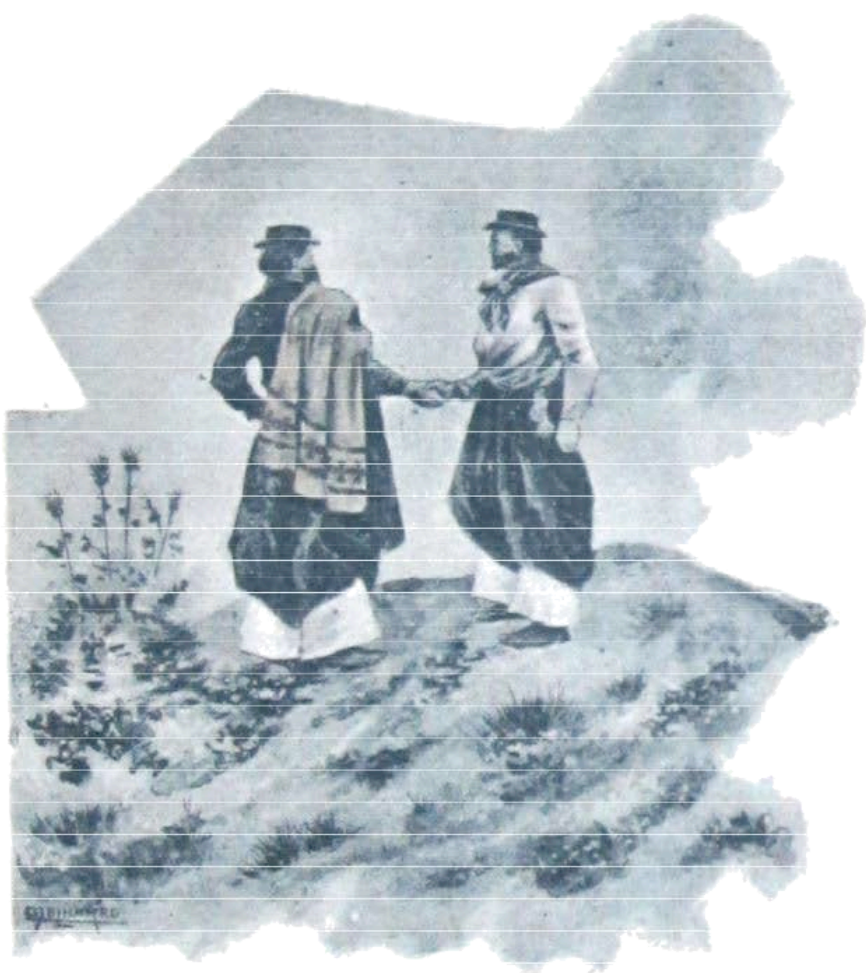

ramas que tapa el cielo tradicionalmente despejado del paisaje pampeano, sugiriendo un inédito horror vacui en la representación del paisaje argentino (fig. 8). Cuando la marcha lleva a los desventurados protagonistas a las cercanías de Leubucó, el paisaje se enmarca elocuentemente en una viñeta con forma de lápida, con calaveras y pájaros negros en primer plano, asumiendo connotaciones netamente simbolistas (fig. 9). 


\section{LXV}

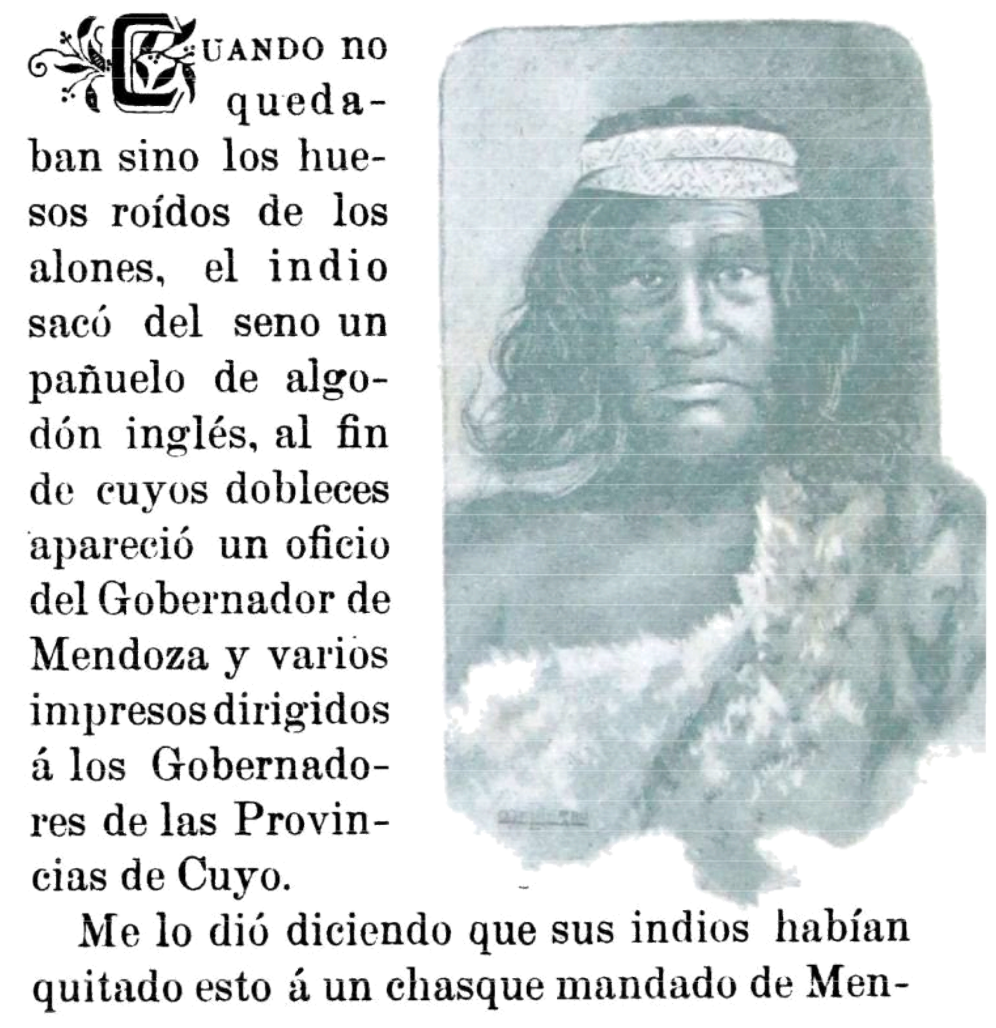

En muchos de los paisajes, que se representan sin personajes, el dibujo desborda los contornos de la lámina, como para sugerir ulteriores posibilidades de visualizar lo que no se muestra (fig. 10). La búsqueda de Malharro se reflejará, en los años siguientes, en pinturas que, en las palabras de Malosetti, "no fueron impresiones captadas en un momento preciso de una realidad objetivable sino resultado de un proceso de simbolización y síntesis de elementos que resultaban de una profunda compenetración con el paisaje nacional: la pampa, sus árboles, sus noches, y sus ranchos a la luz de la luna, los arroyos, las sierras lejanas y azules" (Malosetti, 2008: 13).

Ahora bien, si las viñetas de paisajes son el terreno en el cual Malharro despliega la mayoría de sus recursos expresivos, en cambio, es en la representación de los personajes que el ilustrador parece perder eficacia, o interés. No en el caso de los gauchos, que están retratados con esmero, según la tradición iconográfica que ya por ese entonces se había consolidado e incluso manifestado en distintos estilos y matices. La escena del apretón de manos entre el capitán Gatica y el joven Liberato, en la cumbre de la sierra, marca el pacto para el levantamiento de Cuyo contra la Federación: "Nos dimos un apretón de manos en silencio, sobre la cumbre del cerro, como un juramento solemne de morir por la Libertad de la Patria!" (110). Para el ilustrador es la ocasión de construir una imagen de resonancias épicas, en la cual las figuras varoniles, cuyos perfiles se recortan contra un cielo nublado, se cargan de fuertes sentidos simbólicos: son los auténticos salvadores de la patria (fig. 11).

El verdadero problema parece plantearse con el retrato del personaje indígena mejor caracterizado de la novela, el cacique muluche Pagintú, quien representa el tipo del 'indio amigo', el único sobre el que pueda fundarse un proyecto vagamente integrador 


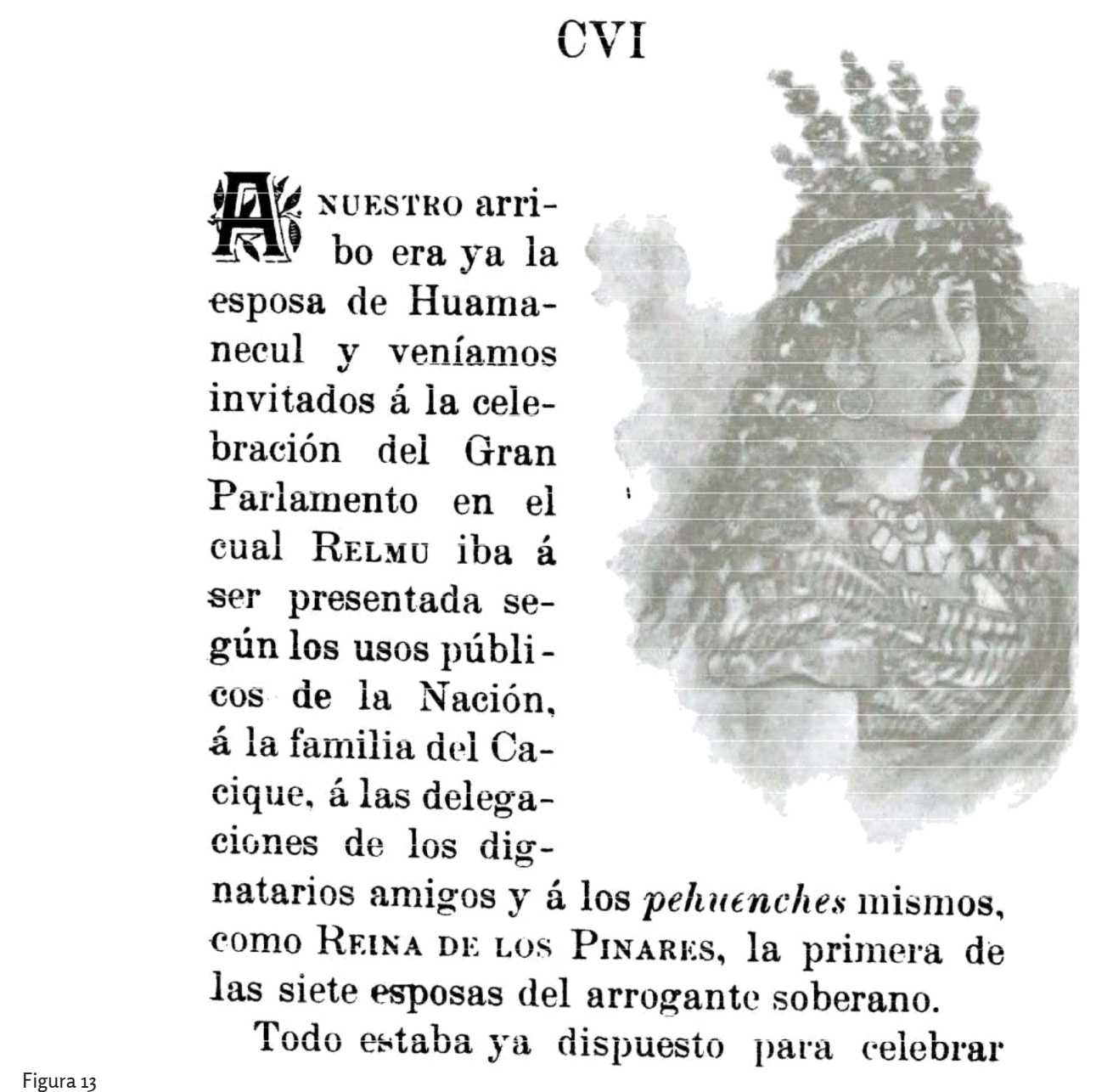

en la narración de la identidad nacional. Integración, por otra parte, finalmente negada en este romance de reminiscencias indianistas, ya que a Panchita, capturada de nuevo por los indios para convertirse en la reina de los pinares, se le negará la posibilidad de coronar su vida conyugal con Liberato y fundar con él una descendencia. Llegado a esta altura del relato, Malharro parece no tener ningún medio para la caracterización de Pagintú, ningún modelo iconográfico al que recurrir, y se limita a retocar una de las fotografías etnográficas más célebres de la serie, la del cacique Casimiro Biguá, de Esteban Gonnet (fig. 12). Imagen fundante de la iconografía fotográfica del indígena en la Argentina (Giordano, 2012: 20), la toma remontaba a 1864, cuando el cacique Casimiro fue recibido con agasajos en Buenos Aires por el presidente Mitre, en ocasión de la ratificación de un tratado, y había sido reproducida innumerables veces, en álbumes litografiados, postales o en la prensa. Casimiro, fotografiado en otras ocasiones vestido con uniforme del ejército argentino, como solían retratarse los 'indios amigos', le presta su imagen al cacique ficcional, causando un brusco viraje en la lectura: el retrato ancla el romance al dato visual histórico, convirténdolo en el relato de lo que hubiera podido ser, espejo de una realidad prudentemente esfumada en el pasado, que puede contemplarse desde un presente nacional cómodamente a salvo de sus amenazas.

Por último, Malharro se tiene que enfrentar con el dilema del retrato de Relmu, es decir de Panchita otra vez cautiva, transformada en esposa del lúbrico cacique Huamanecul, la otra cara de la terribilidad indígena. De nuevo el ilustrador parece dudar en la caracterización del personaje. Es la mujer perdida, la cautiva postergada 
que la Patria no ha sabido salvar, y al mismo tiempo, la reina indígena venerada como símbolo del bien por la tribu de Huamanecul. Malharro la retrata según los cánones de la belleza femenina finisecular, luciendo un peinado y ornamentos inclasificables, y concentrándose sobre todo en los rasgos y en la expresión del rostro, portadores de la infinita tristeza de su condición (fig. 13).

El final de la novela, con la trágica anagnórisis y consecuente desmayo del protagonista, que determina la brusca interrupción de la narración en primera persona, no deja lugar a dudas: así se concluye el romance imposible entre los jóvenes postergados del corazón geográfico de la Patria, que solo recobrará sus condiciones de posibilidad con la conquista y el borramiento, o invisibilización, de los pueblos originarios. Con el desmayo de Liberato también termina la trilogía, y con ella una época que, según Zeballos, marca el advenimiento de otra era para ese "vasto y misterioso territorio, que nombrábamos y describíamos con la palabra pampa".

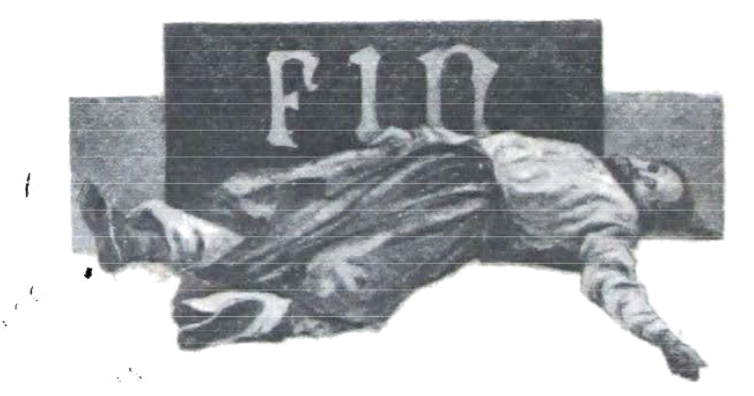




\section{Q Bibliografía}

"De Alba-Koch, B. (1999). Ilustrando la Nueva España. Texto e imagen en el "Periquillo Sarniento" de Fernández de Lizardi. Cáceres: Universidad de Extremadura.

» Genette, G. (2001 [1987]). Umbrales. México-Buenos Aires: Siglo XXI.

» Giordano, M. (2012). Indígenas en la Argentina. Fotografías, 1860-1970. Buenos Aires: Artenauta.

" Gruzinski, S. (1994). La guerra de las imágenes. De Cristóbal Colón a Blade Runner (1492-2019). México: FCE.

"Malosetti Costa, L. (2001). Los primeros modernos. Arte y sociedad en Buenos Aires a fines del siglo XIX. Buenos Aires: FCE.

»Malosetti Costa, L. (2005). “¿Un paisaje abstracto? Transformaciones en la percepción y representación visual del desierto argentino”, en Batticuore, G., GaIlo, K., Myers, J. (compiladores), Resonancias románticas Ensayos sobre historia de la cultura argentina (1820-1890). Buenos Aires: Eudeba, pp. 291-303.

"Malosetti Costa, L. (2008). “Estilo y política en Martín Malharro", Separata, Rosario, Centro de Investigaciones del arte argentino y latinoamericano, UNR, año VIII, núm. 13, diciembre.

» Malosetti Costa, L., Gené, M. (2009). Impresiones porteñas. Imagen y palabra en Ia historia de Buenos Aires. Buenos Aires: Edhasa.

»Malosetti Costa, L., Penhos, M. (1991). “Imágenes para el desierto argentino. Apuntes para una iconografía de la pampa", III Jornadas de Teoría e Historia de las Artes Ciudad/campo en las Artes en Argentina y Latinoamérica, Buenos Aires, CAIA.

»Pas, H. (2014). “Leer (con) imágenes. Litografías y prensa periódica en los procesos de lectura y escritura a mediados del siglo XIX en el Río de la Plata". En Tramas impresas: Publicaciones periódicas argentinas (XIX-XX). La Plata: Universidad Nacional de La Plata. Facultad de Humanidades y Ciencias de la Educación, pp. 64-79.

»Pérez Salas, M. E. (2005a). Costumbrismo y litografía en México, un nuevo modo de ver. México: UNAM.

"Pérez Salas, M. E. (2005b). “Las imágenes en las revistas de la primera mitad del siglo XIX”, en Belem Clark de Lara y Elisa Speckman Guerra, eds., La república de las letras. Asomos a la cultura escrita del México decimonónico, vol. II. Publicaciones periódicas y otros impresos. México: UNAM, pp. 87-103.

"Salvioni, A. (2015). “El silencio de las imágenes. Las ilustraciones a Una excursión a los indios ranqueles”. En Confluenze, 7, pp. 107-136.

»Silvestri, G. (2011). El lugar común. Una historia de las figuras de paisaje en el Río de la Plata. Buenos Aires: Edhasa.

» Szir, S. M. (2009). “Entre el arte y la cultura masiva. Las ilustraciones de la ficción literaria en Caras y caretas (1898-1908)", en Malosetti Costa, L., Gené, M., Impresiones porteñas. Imagen y palabra en la historia de Buenos Aires. Buenos Aires: Edhasa.

»Vignati, M. A. (1947). "Falacias iconográficas”. En Relaciones de la sociedad argentina de antropología, IV (259-262).

"Wechsler, D. (2001). “Identidad y paisaje”, en Pintura argentina. Impresionismo argentino. Banco Velox: Buenos Aires, pp. 18-21. 